\title{
The local government policy strategy in managing waste at the coastal region of central Maluku district
}

\section{Nurlita Pertiwi*, Gufran Darma Dirawan and Wa Karmila}

Engineering Faculty, Universitas Negeri Makassar, Indonesia

Email: nurlita.pertiwi@yahoo.com

Email: gufrandarma@yahoo.com

Email: milamilvy@gmail.com

*Corresponding author

\begin{abstract}
The purpose of this research is to design strategy for government policy on waste management in the coastal region of Central Maluku district. The primary data has been taken by using questionnaire of expert judgment and analysed by using analytical hierarchy process (AHP). The results showed the waste management policy in the coastal region of Central Maluku district developed and implemented by collaboration approach between local government, community and private sector. The most dominant role held by the local government which is Environmental Department Office in the implementation of waste management strategy. Furthermore, the scenario that chosen for community participation is the reduction volume of waste. The strategy can be done by improving people's knowledge, motivation and ability to reduce, reuse and recycle of waste.
\end{abstract}

Keywords: strategy; waste management; coastal.

Reference to this paper should be made as follows: Pertiwi, N., Dirawan, G.D. and Karmila, W. (2015) 'The local government policy strategy in managing waste at the coastal region of central Maluku district', Int. J. Environmental Policy and Decision Making, Vol. 1, No. 4, pp.311-319.

Biographical notes: Nurlita Pertiwi is a Lecturer at Building Engineering Education, Engineering Faculty of Universitas Negeri Makassar. He is a Lecturer at Environmental Education Study Program, Post Graduate Program of Universitas Negeri Makassar.

Gufran Darma Dirawan is a Lecturer at Building Engineering Education, Engineering Faculty of Universitas Negeri Makassar. He is the Chairman of Environmental Education Study Program, Post Graduate Program of Universitas Negeri Makassar.

Wa Karmila is a researcher at Environmental Education Study Program, Post Graduate Program of Universitas Negeri Makassar. 


\section{Introduction}

One of the main problems of current socio-economic activities in Indonesia is how to deal with the increasing amounts of household waste that generated in urban areas. The fact shows in many large cities of Indonesia are suffering from severe problems caused by inappropriate household waste handling and require an integrated management approach involving various players in waste management (Ahemka et al., 2015). Moreover inefficient waste disposal management, particularly in terms of household waste management because of lack of system in its disposal or elimination a number of wastes in community household that may cause major pollution of the environment. This fact will lead to waste generally affected the environment not only in changing the physical feature surrounding but also affected the conduciveness of human living environment. Inefficient management of waste disposal may cause air, water, odour pollution and damage esthetic values of the surrounding areas. Collectively unmanaged waste may adversely affect human health and living condition (Sakawi et al., 2013).

Waste problem become more difficult to overcome in some coastal areas of Indonesia. Many aspects influence factors so that the waste problem is seen and became as a chain effect that has no solution. In the organisational structure of local government, various work units are authorised in the resolution of the problem of waste. The government policy cannot be implemented because of lack effective of strategy and financial problem in the level of district authority. In addition, there are several stakeholders should be involved in the matter of reducing the waste and involve in the management of waste, such as: private agencies and university. Therefore, there is a need to improve cooperation between all parties or stakeholders, namely the government, private sector, and communities. Moreover, analysis of government policy was made to assess the actions to be taken in dealing with the problem of waste in coastal areas. In addition, policy analysis in this term should be force to generate and transform the information that needed for government policy by using various methods of research and discussion in a certain condition to solve a problem (Dunn, 2004).

The fact shows that coastal residential area in Central Maluku district was facing the numerous problem of waste management. The available facilities at the settlements in coastal areas such as water, roads, drainage is in good condition. But in terms of waste management services is not adequate. There is no waste facility such as temporary shelters in the coastal areas and resulted final disposal coastal area is dumped into the seashore. As a result, residential coastal areas of Central Maluku district looks less clean because of the accumulation of rubbish and occur untidiness. Furthermore, the amount of garbage on the coastal area is also a source of diseases such as diarrhea, typhoid and dengue fever and will threaten people's lives. Therefore there is a need to improve waste management by using effective strategy to resolve a comprehensive policy. Starting from the changes in people's behaviour as an indicator of participation in environmental preservation.

In terms of the settlements in the coastal areas of Central Maluku district is a challenge for local authorities to create and develop fundamental policy. Therefore, the study aims to design a strategy of government policy on waste management in the coastal region of Central Maluku. 


\section{Research methods}

This study is a survey by using a quantitative approach which is located in Central Maluku. The research activities take place in May to July 2014. The sample was considered to be an expert judgement who understand the waste management policy by using purposive sampling technique, the sample of experts in this study amounted to seven people, consisting of Head of Regional Development Planning Agency, Head of Environmental Office, Section Head of Building Management and Settlements Department of Public Works, Section Head of Spatial, Deputy of Director of Non-Governmental Organization (NGO), The Chairman of study program of Environmental Education Universitas Negeri Makassar and Head of Residential Unit in the Central Maluku.

Table 1 The fundamental scale of absolute numbers

\begin{tabular}{|c|c|c|}
\hline $\begin{array}{l}\text { Intensity of } \\
\text { importance }\end{array}$ & Definition & Explanation \\
\hline 1 & Equal importance & $\begin{array}{l}\text { Two activities contribute equally to the } \\
\text { objective }\end{array}$ \\
\hline 2 & Weak or slight & \\
\hline 3 & Moderate importance & $\begin{array}{l}\text { Experience and judgement slightly favour one } \\
\text { activity over another }\end{array}$ \\
\hline 4 & Moderate plus & \\
\hline 5 & Strong importance & $\begin{array}{l}\text { Experience and judgment strongly favour one } \\
\text { activity over another }\end{array}$ \\
\hline 6 & Strong plus & \\
\hline 7 & $\begin{array}{l}\text { Very strong or demonstrated } \\
\text { importance }\end{array}$ & $\begin{array}{l}\text { An activity is favoured very strongly over } \\
\text { another; its dominance demonstrated in } \\
\text { practice }\end{array}$ \\
\hline 8 & Very, very strong & \\
\hline 9 & Extreme importance & $\begin{array}{l}\text { The evidence favouring one activity over } \\
\text { another is of the highest possible order of } \\
\text { affirmation }\end{array}$ \\
\hline $\begin{array}{l}\text { Reciprocals } \\
\text { of above }\end{array}$ & $\begin{array}{l}\text { If activity } i \text { has one of the } \\
\text { above non-zero numbers } \\
\text { assigned to it when compared } \\
\text { with activity } j \text {, then } j \text { has the } \\
\text { reciprocal value when } \\
\text { compared with } i\end{array}$ & \\
\hline $1.1-1.9$ & If the activities are very close & $\begin{array}{l}\text { May be difficult to assign the best value but } \\
\text { when compared with other contrasting } \\
\text { activities the size of the small numbers would } \\
\text { not be too noticeable, yet they can still } \\
\text { indicate the relative importance of the } \\
\text { activities }\end{array}$ \\
\hline
\end{tabular}

Source: Saaty (2008)

The instrument used was a questionnaire that contains nine of possible answers in each question. Data analysis was performed using analytical hierarchy process (AHP). The step of AHP is preparation of pairwise comparison matrix that describes the relative 
influence or effect of each element on each goal level above it. Secondly, comparison based on the judgment of stakeholders to judge the importance of the element compared to the other elements (Marimin, 2005). To quantify the qualitative data used comparative scale of 1-9 based on the value scale (Saaty, 2008) shown in Table 1.

The output of the analysis is to analyse and design strategic policy for waste management and develop scenario for policy implementation and the waste management strategy in coastal areas in Central Maluku district.

\section{Results and discussion}

\subsection{Consistency ratio analysis}

One of the decision-making models that can be used for the determination of policy for waste management in the coastal region of Central Maluku is using AHP which helped compile strategic priority management of the various options using multiple criteria (multi-criteria) analysis. The results of the analysis of consistency ratio is a combination of opinion the experts, on Table 2 shows consistent values of AHP.

Table 2 Results of consistency ratio calculation matrix composite opinions

\begin{tabular}{lcccc}
\hline Criteria & Matrix size & CR & CR maximal & Information \\
\hline Stakeholders & $3 \times 3$ & 0 & 0.03 & Consistent \\
Authority & $5 \times 5$ & 0.05 & 0.1 & Consistent \\
Scenario & $4 \times 4$ & 0.01 & 0.08 & Consistent \\
Strategy & $3 \times 3$ & 0 & 0.03 & Consistent \\
\hline
\end{tabular}

Based on this analysis, it can be stated that all the criteria of strategic policy of waste management is under consistency ratio. Therefore, the next step is preparation of the next hierarchy weight value by calculating strategic priority at every level of criteria and sub criteria. The results obtained from the preparation of a five-level hierarchy are the focus, the stakeholders, the authorities, the scenarios of community participation, and strategies.

\subsection{Priority on level stakeholders and authority}

The results of the analysis of the role of the stakeholders who were involved in waste management in coastal areas can be seen on the Figure 1. It is shows the importance of stakeholders and the most responsible stakeholders in waste management in coastal areas.

The result of analysis shows that the government and community play significant role in waste management. Both of them have no significance difference. In terms of waste management strategic authorities at the coastal region of Central Maluku district regency. The policy can implemented with the support of community participation by empower community based on household. The weight of government is 0.471 while a community stakeholder has weight 0.452 . The weight value shows the management value in AHP to find the role in waste management. 
Figure 1 Priority weights at level stakeholders (see online version for colours)

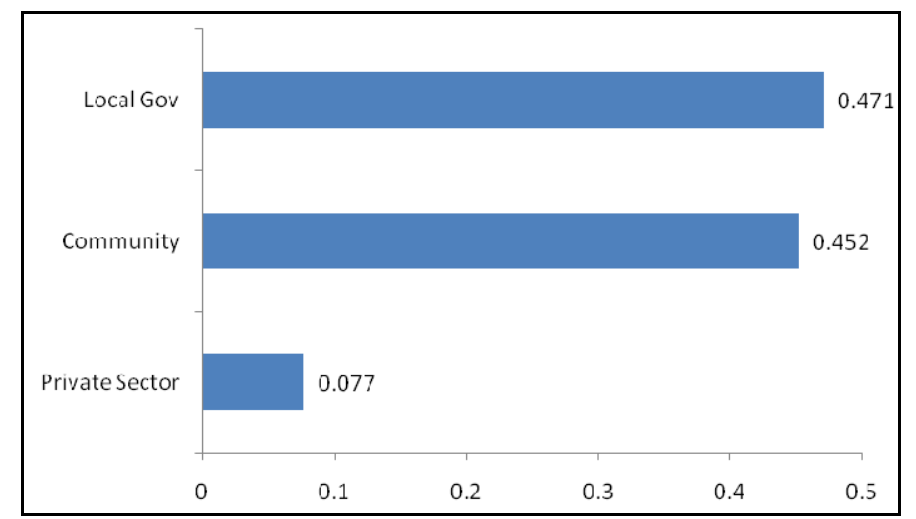

Figure 2 Priority weights at level authority (see online version for colours)

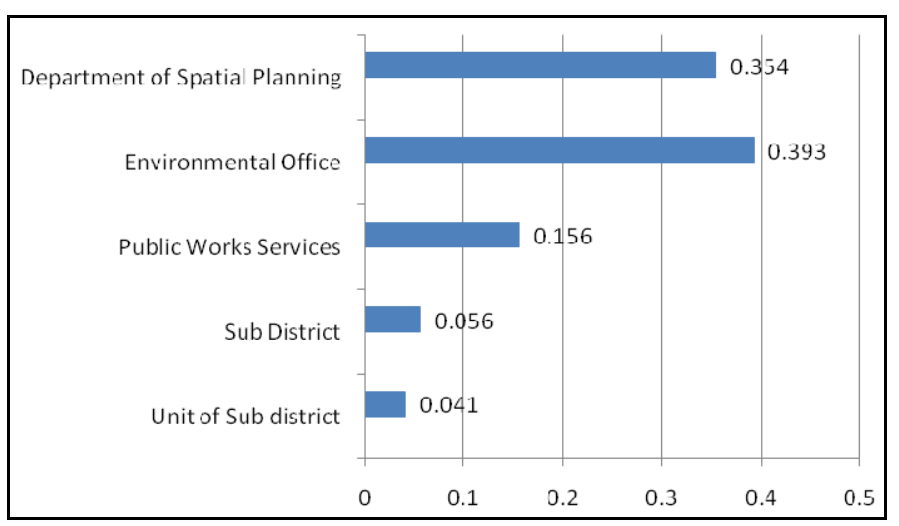

Furthermore, the Figure 2 shows the level authority for priority weight of level authority government agencies which have a major role in waste management are the Environmental Office. It can be seen on the Figure 2.

As can be seen from the Figure 2 that local government policy-making in waste management in coastal areas requires powers to manage community disposal. The local government agencies who has authorities is Environmental Office of Central Maluku who scored highest priority weight is 0.393 . The second authority who have more powerful role is Department of Spatial Planning obtain a second weight value is 0.354 and the third authority gain weight value that the Public Works Services is 0.156 . Authority from the district to obtain the value of the fourth priority weight is 0.056 while the unit of sub district got the lowest weight value is 0.041 .

The role Environmental Office is to control damage and environmental pollution. This work unit was deal in the planning and provision of facilities for waste transport in urban areas. While, Department of Spatial planning has role to improve the housing environmental quality and residential area the unit is responsible for the provision of facilities and infrastructures of waste in houses and residential areas. Therefore, Environmental Office and Department of Spatial Planning have to work together in 
implementation waste management strategic for improving the quality of urban environment.

\subsection{Priority on public participation level}

The second criteria is the role of community or community participation in managing their waste in the coastal region of Central Maluku district analysed on four criteria i.e.; Firstly; waste management financial issues. Secondly: waste management reduction volume programs. Thirdly; waste management supervision for community empowerment. Finally; waste management provision of infrastructure facilities the results of the analysis can be seen in Figure 3.

Figure 3 Priority weights at level scenario public participation (see online version for colours)

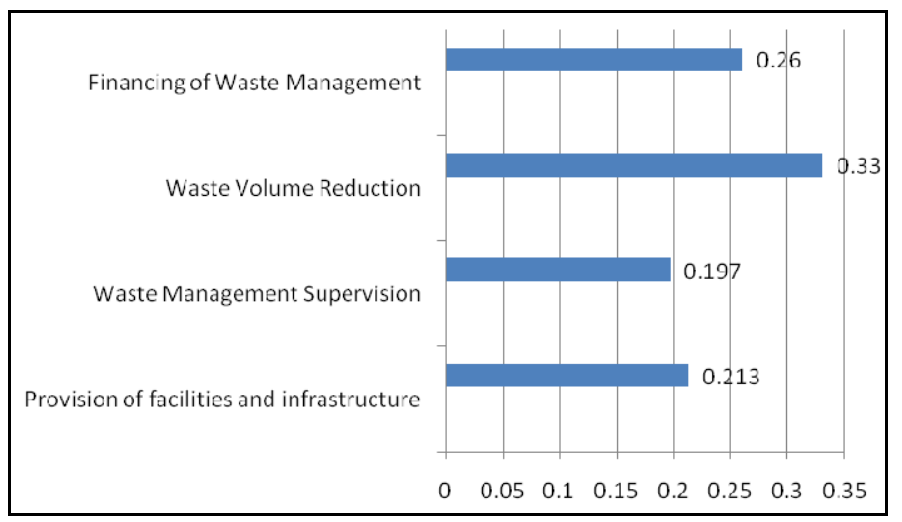

Figure 3 shows that the role of the community in the management of garbage in coastal areas should be done by reducing the volume of waste start from households because of the effort does not require huge costs and high technology, most of the households can be actively involved in this strategy by create adaptive programs such as create waste community and waste banking system. Furthermore, the second strategy that is needed to improve is the financing of waste management. Being the provision of infrastructure and supervision by the public has a relatively small value.

\subsection{Waste management strategy}

Waste management strategy by the government analysed by using the three criteria. Firstly; increase in people's behaviour in reducing the volume of waste. Secondly; increase recycling activities, and thirdly; provision of waste facilities and infrastructure. The result of the analysis of priority weight calculation is presented in Figure 4.

Figure 4 shows that the strategy to do the local government is to improve people's behaviour in reducing waste volume weight gain priority value 0.545 . In addition, strategies to obtain a second priority is increased activity in waste recycling by 0.326 priority weight, gain weight while the lowest priority is the provision of facilities and infrastructure by local governments, namely 0.129 . 
Figure 4 Priority weights at level strategy (see online version for colours)

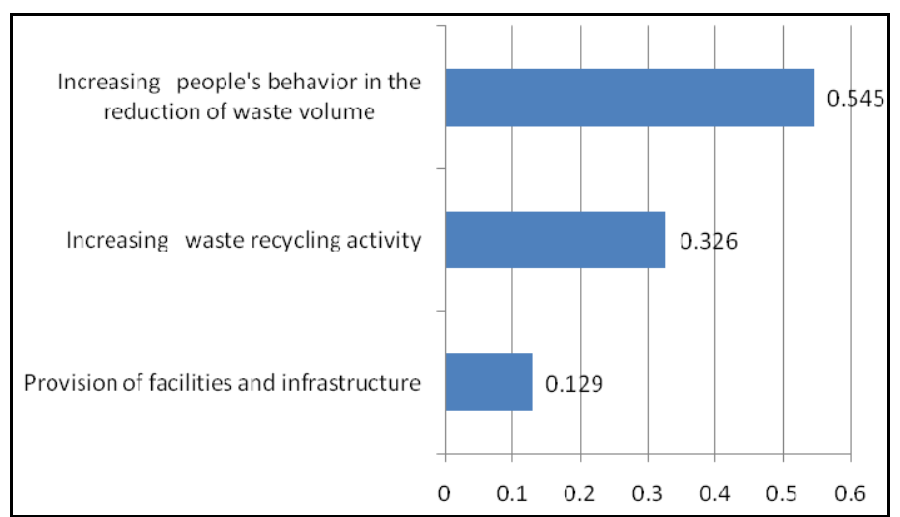

\subsection{Discussion}

\subsubsection{Community participation}

The role of the community on waste management in the coastal area is characterised by human behaviour. In managing their livelihood especially in reducing waste based in household in conjunction with the theory of behaviour (Hungerford and Volk, 1990) revealed that the behaviour and sense of responsibility to the environment caused by two factors, namely things: the tendency to act (Intention to act) and situtational factor (factor of the situation). Human tendency to act is affected by two things: the personality factor (internal factor of human) and knowledge of environmental issues (knowledge of issues). Agussalim (2014) revealed that ecological behaviour in coastal management is affected directly and indirectly by environmental knowledge, local wisdom and locus of control.

Community participation in waste management must be preceded by efforts to increase knowledge on environmental issues. In waste management, the major public knowledge is knowledge in reducing the volume of waste by using 3R program (reduce, reuse and recycle). This program seems not effective in first. However, it is require communication media in community level.

Efforts waste volume reduction can be achieved by $3 \mathrm{R}$ programs (reduce, reuse, and recycle). Efforts to reduce (waste reduction) are:

a Community behaviours to support waste reduction in quantity, such as buying food, beverages with biodegradable packaging.

b The use of refill products on a variety of needs such as cooking oil or sauce.

c The use of plastic bottle waste can be reduced. Reuse (reuse) or avoid disposable goods (disposable), such as carrying and using their own plastic bags when shopping, or use the next page of the paper that has been used.

d It can be extend the use of the goods before it becomes garbage. And subsequent recycle (recycle), which sought the use of materials that are not used anymore to be recycled into something that can be utilised, such as the use of plastic bottles as flower pots, keychain, or decorations in the house. The waste should be split between 
organic and inorganic. Organic waste can be composted, so that each part can be composted or recycled optimally.

The fact also shows recycle method can reduce the volume of inorganic waste. Inorganic waste which amounts to $44 \%$, with the recycle method, the volume can be reduced up to $25 \%$ of the amount of trash or $19 \%$ reduction in waste volume. Furthermore, method or processing waste composter composting is a way of accumulation of garbage in a small hole in a certain period of time to produce a natural fertiliser or decomposition process conducted by the microorganisms of the biodegradable organic effluent can reduce the volume of organic waste by $21.56 \%$ (Surjandari et al., 2009).

\subsubsection{Government rule}

Community involvement in the decision-making of waste management in the coastal region is also mandated by national regulation Number 18 of 2008 on Waste Management. The regulation required people participate in the provision of advice and opinions in the formulation of policies and strategies for waste management. Community, especially in coastal areas other than as program implementers in the implementation of the policy, will also receive a major impact due to the ineffectiveness of the policy. By them, the public participation in the preparation of waste management policy should also be a priority.

Government through the national policy of Waste Management even requires each manufacturer to manage the packaging or product which cannot or difficult to decompose by natural processes such as the withdrawal of the packaging to be recycled or reused. Furthermore, in article 11 stated that the reduction of waste volume can be done through restriction of garbage, waste recycling and reuse waste. These activities cannot be separated from the role of local government in providing appeal and outreach to the community, to reduce the volume of waste that can be done by using materials that can be reused, materials which can be recycled, and or material that is easily decomposed by natural processes, as well as collecting and handing back the garbage of the product or packaging that has been used.

\subsubsection{Strategic policy}

A waste management policy strategy in the coastal areas of Central Maluku district is to increase people's behaviour in the reduction of waste volume. The programs that can be done include:

a Integrating knowledge or concept of 3R (reduce, reuse, recycle) in community-based activities.

b Disseminating the program 3R (reduce, reuse, recycle) through billboards in schools and offices.

c Applying composter in regions producing organic waste, such as in traditional markets and households.

d Make announcements or inform the prohibition to throw garbage into the sea coast or (supported by the provision of facilities and infrastructure and the implementation of local regulations). 
e Visualise the negative impact of coastal environmental pollution due to waste through posters and billboards.

f Forming non-governmental organisations (NGOs) and youth organisations engaged in the environmental field.

\section{Conclusions}

The waste management policy in the coastal region of Central Maluku district developed and implemented by collaboration approach between local government, community and private sector. The most dominant role held by the local government which Environmental Department Office plays dominant role in the implementation of waste management strategy. Furthermore, the scenario that chosen for community participation is the reduction volume of waste. The strategy can be done by improving people's knowledge, motivation and ability to reduce, reuse and recycle of waste.

\section{References}

Agussalim, Dirawan, G.D., Mulyadi and Rauf, B. (2014) 'The ecological behaviour of community in preserving land use in coastal areas of parepare', Journal of Environmental Science and Technology, Asian Network for Scientific Information, Vol. 7, No. 4, pp.218-225, DOI: 10.3923/jest.2014.218.225

Ahemka, A. Higano, Y.H., Mizunoya, T. and Yabar, H. (2015) 'An overview of current household waste management in Indonesia: development of a new integrated strategy', International Journal of Environment and Waste Management, Vol. 15, No. 1, pp.86-98.

Dunn, W.N. (2004) Translation for Public Policy Analysis, Gajah Mada University Press, Yogjakarta.

Hungerford, H. and Volk, T.L. (1990) 'Changing learner behavior through environmental education', Journal of Environmental Education, Spring, Illinois, USA, Vol. 21, No. 3, pp.8-21.

Marimin (2005) Compound Criteria Decision Making, Grasindo, Jakarta.

Saaty, T. (2008) 'Decision making with the analytic hierarchy process', Int. J. Services Sciences, Vol. 1, No. 1, pp.83-98.

Sakawi, Z., Nor, A.R., Rostam, K., Ayup, S. and Jali, M.F.M. (2013) 'The perception of the coastal community on the management of solid waste disposal along the Johor South Coast', The Social Sciences, Medwell Journal, Vol. 8, No. 2, pp.166-171.

Surjandari, I., Hidayanto, A. and Supriatna, A. (2009) 'Dynamic model of waste management to reduce expenses stacking', Journal of Industrial Engineering, December, Vol. 11, No. 2, pp.134-147. 